\title{
MOSONINÉ FRIED JUDIT: AZ INNOVÁCIÓ NÉVTELEN HÁTORSZÁGA
}

\author{
A külföldi múködőtőke multiplikátor hatása
}

(MTA Kutatás-és Szervezet-Elemzö Intézet, Budapest, 1997. p. 163)

\section{DÖRY TIBOR}

Az Országos Műszaki Fejlesztési Bizottság (OMFB) gondozásában jelent meg a fenti címmel az a tanulmánykötet, amely a külföldi befektetések szerepével, hatásával foglalkozik. Az utóbbi néhány évben élénken foglalkoztatja a gazdaságkutatókat, hogy az országba áramlott jelentős mennyiségủ (közel 18 milliárd dollár értékú) kủlföldi tőke milyen hatást gyakorol a magyar gazdaságra, annak fejlödésére. Különơs hangsúlyt érdemel azonban az is, hogy az itt letelepedett vállalkozások, milyen mértékben hasznositják a magyar szakemberek, kiemelten a kutatók, fejlesztők tudását. Ezekre a kérdésekre vonatkozólag eddig csak egyes vállalatok tapasztalatain alapuló találgatások láttak napvilágot, $s$ a szerzö éppen arra tett kísérletet, hogy empirikus vizsgálatok, interjúk segitségével bizonyítékokra támaszkodó eredményekkel tudjon szolgálni.

A kutatást két nagyobb szakaszra bontották: elöször a külföldi tőke makrogazdasági és innovációs hatásaival kapcsolatos nemzetközi tapasztalatokkal foglalkoztak, majd a második részben kérdöíves felmérések és a nagyobb vállalatok, kutatóintézetek vezetöivel készített interjúk eredményeit mutatták be. Jelen recenzió természetesen nem térhet ki minden megállapitás, tapasztalat ismertetésére, inkább csak utalásszerüen jelzi a fontosabb eredményeket.

A külföldi müködőtôke makrogazdasági és innovációs hatásának elemzése meglehetösen új területnek számít, hiszen Magyarországon csak az elmúlt 3-4 évben szullettek ilyen témájú irások. A hazai kutatók leginkább a privatizált vállalatok megváltozott helyzetével foglalkoztak, és inkább csak esettanulmányok során tértek ki arra a kérdésre, hogy mit jelent a külföldi töke megjelenése olyan vállalatoknál, amelyeknél korábban jelentős müszaki fejlesztési tevékenység folyt.

$\mathrm{Az}$ első szakasz a külföldi tőkeáramlás hatás-elméleteinek ismertetésével ("délkelet-ázsai-modell", "afrikai-modell" és a "latin-amerikai-modell"), majd a külföldi tỏkebefektetések motivációs tényezőinek elemzésével, ill. a legnagyobb magyarországi beruházók (GE, GM, AUDI, stb.) bemutatásával indul. Megállapítja, hogy "... a fejlett országokból érkezó tỏkeexportot sokféle tényezó motiválja a befektetök részéről. A leggyakrabban említettek a következők:

- piacszerzés,

- alacsony bérköltség,

- az állami tulajdon olcsó felvásárlásnak lehetősége,

- jelentős adó- és vámkedvezmények,

- a szigorú környezetvédelmi követelmények hiánya,

- kedvezö keresleti szint bizonyos szolgáltatások és új termékek iránt,

- $\quad$ az egyes valuták alulértékeltsége, árfolyamnyereség elérhetősége." 
Amint az a fenti befektetési szempontok áttekintéséböl is kiderül, a szellemi potenciál hasznosítása nem szerepel a motivációs tényezök között. Az országban lezajlott magánositás, a megtelepedett vállalkozások fejlesztése azonban új megvilágításba helyezheti ezt a szempontot is, hiszen "... a külfooldi müködőtóke hatása makrogazdasági szempontból nem mindig, nem közvetlenül és nem azonnal mutatható ki. A tökebeáramlás hatása - a másodlagos hatás egy része - kimutatható olyan empirikus vizsgálatokon keresztül is, amelyek a vállalatok egymás közötti kapcsolatairól és azok változásáról adnak képet."

A nagy- és kisvállalkozások egyuittmükődésének formáját és erősségét leginkább a tartalom határozza meg, amely szerint négy alapvető típust különbozztethető meg:

1. viszonylag laza termelési kapcsolat,

2. szoros termelési kapcsolat,

3. stratégiai partneri viszony,

4. szolgáltató funkció alapján kialakuló együttmüködés.

Az 1990 utáni beszállítói kapcsolatok alakulásáról a szerzö azt a következtetést vonja le, hogy müszaki szempontból majdnem jelentéktelen a magyar és a külföldi vállalatok közötti kapcsolatrendszer sőt, még a korábban jól müködö belfơldi egyuuttmükődések is megszakadtak a külföldi tulajdonosok megjelenésével. Felhívja a figyelmet azonban arra, hogy nagyon fontos a multik másodlagos hatása, ami különbözö formákban ölthet testet:

- a külfơldi leányvállalat beszállítóira és termékeinek fogyasztóira gyakorolt hatás,

- a helyi versenytársakra gyakorolt hatás,

- a tőbbi munkaadóra, a munkaerő fluktuáciojjára gyakorolt hatás.

A tanulmányban bemutatott svéd vizsgálat szerint akkor kerül sor külföldi $\mathrm{K}+\mathrm{F}$ bázis létesítésére, felvásárlására, ha az a helyi termelést segíti, illetve olyan pluszt tud nyújtani a helyi $\mathrm{K}+\mathrm{F}$ részleg, amivel hozzájárulhat a multinacionális vállalat versenyképességének növeléséhez, legalább is profitja növekedéséhez. Egy másik idézett vizsgálat spanyol tapasztalatok alapján azt a következtetést vonja le, hogy a leányvállalatok maguk is végeznek fejlesztést, elsösorban termékfejlesztést. Igaz ugyan, hogy a saját fejlesztések számánál nagyobb az import aránya, de nem annyival, amennyivel a $\mathrm{K}+\mathrm{F}$ koncentrációjáról szóló elméletek alapján várható lenne. Ugyanakkor megállapitható, hogy a multinacionális vállalatok zárt egységet alkotnak. sokkal kevesebb technológiát, tudást szereznek be akár belföldi, akár külföldi cégektöl, mint vállalatcsoporton belülröl.

Az eddig rendkívül vegyes hazai tapasztalatok, az innovációs folyamatokról szóló vizsgálatok eredményei azt mutatják, hogy csak részterületeken indult meg a fejlödés, a szerző azonban azt a hipotézist fogalmazza meg, hogy "... a $\mathrm{K}+\mathrm{F}$ szektor fejlödésének egyik lehetöségét éppen a kưlföldi tơkebefektetések növekedése teremtheti meg." 
A tanulmány második része a vállalati megkérdezések, interjúk eredményeit tárgyalja. Ennek sorån a következö következtetẻseket vonja le a szerzö:

- A feltételezésekhez képest sokkal innovativabbak a hazai tulajdonban lévő, múszaki fejlesztéssel is foglalkozó vállalkozások.

- A külföldi tulajdonban lévő vállalatok - a megfigyelhető kapcsolódási pontok ellenére is sokkal inkább a nemzetközi, mintsem a hazai innovációs rendszer részét képezik.

- A külföldi társaságok gazdasági szerepe sokkal erösebb, mint az innovációs folyamatokat erösítő szerepük.

- A hazai és a külföldi szervezetek közötti kapcsolatok inkább eladó-vevői jellegủek, valódi partneri kapcsolatot csak ritkán takarnak.

- A potenciális innovációs partnerek többségét felvásárolták a külföldi cégek, a versenyképes $\mathrm{K}+\mathrm{F}$ mühelyek külföldi tulajdonba kerültek.

- A kisebb külfỏldi cégek több lehetöséget biztosítanak a hazai $\mathrm{K}+\mathrm{F}$ irányok és ambíciók megörzésére.

- Idő kell ahhoz, hogy a külföldiek megismerkedhessenek a magyar lehetöségekkel.

- A magyar vállalkozásoknak közös $\mathrm{K}+\mathrm{F}$-re kevés, beszállításra egyre több lehetősége adódik.

- A beszállitás akkor is nagy lehetőség, ha hazai cég (pl. RÁBA, IKARUS) a megrendelö.

- A vállalkozáson kívüli multiplikátor hatás sokkal erősebb, mint amit egy leányvállalaton belül fejt ki az új tulajdonos.

A tanulmány szerzőjének véleménye szerint "minél több a külföldi szereplő a gazdaságban, annál nyilvánvalóbb, hogy:

- A külföldi müködötőke jelenléte mobilizálja a meglévő erőforrásokat: felgyorsítja az önfejlödést.

- Versenyre, versengésre ösztönöz: kihívást jelent.

- Segíti a nemzetközi integrációt.

Azonban ezzel egyidejüleg:

- A megtermelt jövedelem jelentỏs részét kivonja az adott gazdaságból.

- Nagyon erősen és kizárólag a saját érdekei szerint szelektál.

- Gyengíti a belső integrációt."

A külföldi töke gazdasági és politikai szerepe a tanulmány végkicsengése szerint inkább kedvezö, mint kedvezőtlen. Söt, a beszállítói és föként az egyetemekkel kötött szerzödéses kapcsolatok révén, spontán módon megy végbe az innovációs együttmüködések megerősödése. Ehhez azonban meg kell erösiteni a hazai gazdasági és intézményi bázisok innovációs képességét, az oktatástól a fejlesztési eredmények piaci bevezetésén keresztül a beruházásokig, ami a hazai gazdaság- és technológiapolitika feladata. Kívánatos továbbá, hogy a megtelepedett vállalkozások a jelenleginél jobban megismerjék és hasznosítsák az egyetemek és a kutatóintézetek fejlesztési és kutatási eredményeit. 